\title{
Distributions of Indo-Pacific lionfishes Pterois spp. in their native ranges: implications for the Atlantic invasion
}

\author{
Michel Kulbicki ${ }^{1, *}$, James Beets, Pascale Chabanet, Katherine Cure, Emily Darling, \\ Sergio R. Floeter, René Galzin, Alison Green, Mireille Harmelin-Vivien, \\ Mark Hixon, Yves Letourneur, Thierry Lison de Loma, Tim McClanahan, \\ Jennifer McIlwain, Gérard MouTham, Robert Myers, Jennifer K. O'Leary, \\ Serge Planes, Laurent Vigliola, Laurent Wantiez
}

${ }^{1}$ Laboratoire d'Excellence «Corail» Institute for Research and Development, Laboratoire Arago, 66651 Banyuls-sur-mer, France

\begin{abstract}
Lionfish (Pterois volitans and P. miles) have become a major concern in the western Atlantic and Caribbean since their introduction in the 1980s. Invasive lionfish can reach very high population densities on coral reefs in their invaded range, yet there are few data from their native range in the Indo-Pacific for comparison. We compiled data on the geographical distribution and density of Indo-Pacific lionfishes in their native ranges from published and unpublished underwater visual censuses and field collections. We found that lionfish in their native Indo-Pacific range are unevenly distributed, with higher densities in the Indian Ocean than in the Pacific. Lionfish densities increase significantly with increasing latitude, and are significantly higher in continental areas than around islands. In the Indo-Pacific, lionfishes are found not only on reefs but also on soft bottoms and in nearshore habitats such as seagrass beds and mangroves, and near estuaries. Native lionfish can be found at depths greater than $75 \mathrm{~m}$. Because lionfish can be cryptic and secretive, we estimate that only $\sim 1 / 8$ of Indo-Pacific lionfishes are detected during general underwater visual censuses. In the Pacific Ocean, the relative abundance of lionfish in the catch of reef-fish larvae is of the same order of magnitude as the relative abundance of adult lionfish within reef fish assemblages. Overall the observed densities of lionfishes in the Indo-Pacific are much lower (max. 26.3 fish ha ${ }^{-1}$ ) than the densities reported in their invaded Atlantic range (max. 400 fish ha ${ }^{-1}$ ). We found no effects of fishing or pollution on the densities of lionfishes.
\end{abstract}

KEY WORDS: Pterois $\cdot$ Indo-Pacific $\cdot$ Ecology $\cdot$ Visual census $\cdot$ Larvae $\cdot$ Invasive species

\section{INTRODUCTION}

Invasive species are widely considered to be a major threat to native ecosystems from the perspectives of ecology (Molnar et al. 2008, Lambertini et al. 2011), evolution (Mooney \& Cleland 2001), and economics (Pimentel et al. 2005). Addressing invasions requires knowledge of the ecology of invasive species in their native range.
Over the past decade, 2 species of lionfish (Pterois volitans and $P$. miles) native to the Indo-Pacific (Fig. 1) have become invasive species in the western Atlantic and Caribbean (Hare \& Whitfield 2003, Morris \& Whitfield 2009). Collectively, these 2 species rapidly expanded their initial ranges off Florida (Whitfield et al. 2002, Freshwater et al. 2009), and now inhabit most of the region between Cape Hatteras (North Carolina) to the north and Venezuela to 

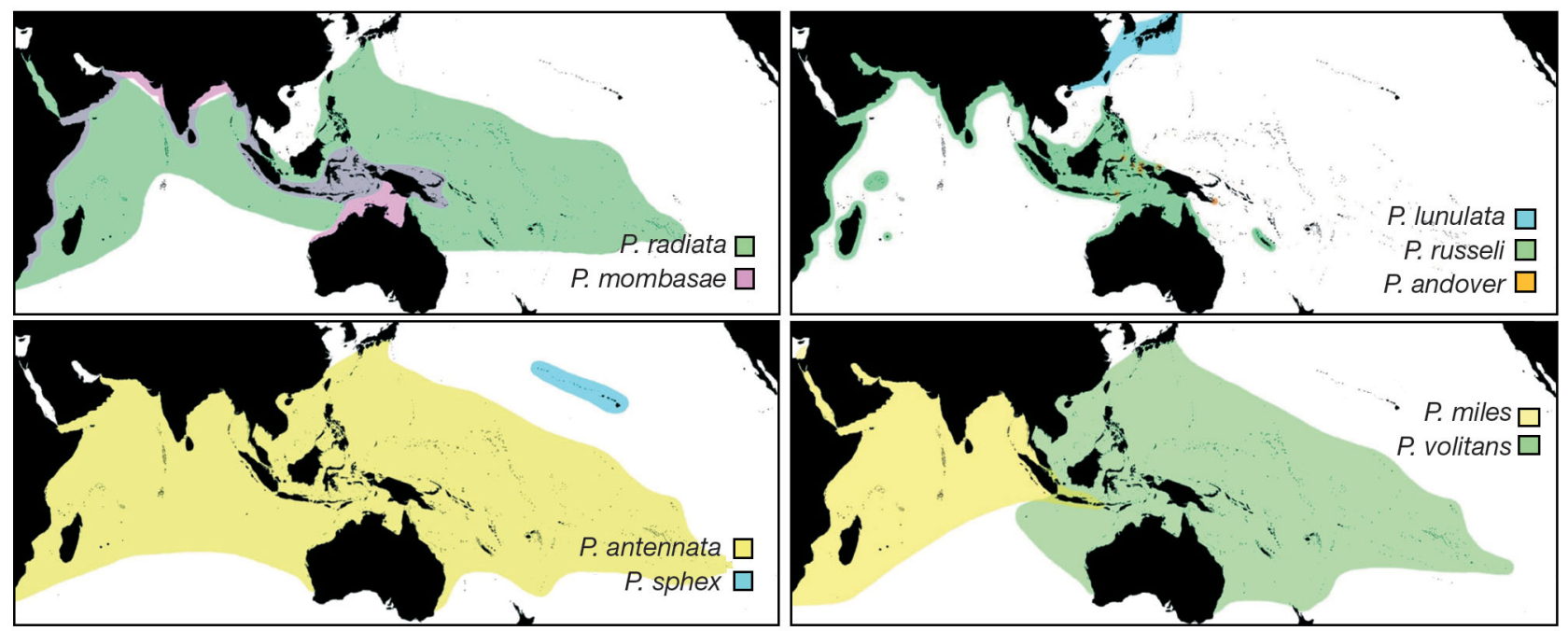

Fig. 1. Pterois spp. Geographical distribution of the 9 native lionfish species in the Indo-Pacific region

the south (Schofield 2009), with recent expansions into the Gulf of Mexico and the Lesser Antilles. (Juveniles are found as far north as Rhode Island, but do not survive over winter.) It is expected that lionfish will soon be found in all coastal waters with temperatures above their lethal limit of $10^{\circ} \mathrm{C}$ in the western Atlantic, extending as far south as the Brazil-Uruguay border (Kimball et al. 2004). Invasive lionfish have broad diets of small crustaceans and especially fishes (Morris \& Akins 2009, Muñoz et al. 2011), and exhibit high kill rates (Côté \& Maljković 2010). An individual invasive $P$. volitans is capable of reducing the recruitment of native fishes on small patch reefs by about $80 \%$ in $5 \mathrm{wk}$ (Albins \& Hixon 2008), so there is justifiable concern that this may become one of the worst marine invasions in history (Albins \& Hixon 2011).

Although the invasion is rapidly expanding, information on the biology and ecology of lionfishes in their Indo-Pacific range is still largely anecdotal (Morris et al. 2009, Morris \& Whitfield 2009). By contrast, information on lionfishes in the invaded regions is rapidly expanding, with studies focused on invasive lionfish distribution and abundance (Whitfield et al. 2002, 2007, Schofield 2009, 2010, Darling et al. 2011), reproduction (Ruiz-Carus et al. 2006, Morris et al. 2011), larval duration (Ahrenholz \& Morris 2010), population genetics (Hamner et al. 2007, Freshwater et al. 2009), food habits (Albins \& Hixon 2008, Morris \& Akins 2009, Côté \& Maljković 2010, Muñoz et al. 2011), and ecological impacts (Albins \& Hixon 2008, 2011).

As is true of many invasive species, lionfishes can reach very high densities, even to $>400$ fish $h^{-1}$ in some areas of the SE United States (Morris \& Whitfield 2009) and the Bahamas (Green \& Côté 2009), which is considerably higher than any densities so far described from their native range (seldom $>10$ fish ha ${ }^{-1}$; Green \& Côté 2009, Grubich et al. 2009).

Our objective was to facilitate a better understanding of the lionfish invasion and its potential threats to Atlantic coral reefs by compiling and analyzing data from multiple sources in order to document the distribution and abundance of the fish in their native range. Our approach was original in several ways. First, we addressed factors such as predation, competition, biogeography and dispersal that may limit these species in their native range, and we discussed how these factors might influence their Atlantic invasion. Second, we compared the relationships between lionfish and their regional trophic structure (e.g. predators, competitors) in the native and invaded ranges. Third, we examined habitat use by lionfishes in both their native and invaded ranges to assess the capacity of these species to colonize new regions. Overall, we went beyond the simple compilation of data of invasive lionfish in their native range. We took a macroecological approach to species invasions in order to evaluate the potential effects of large-scale factors on the dynamics of the lionfish invasion.

\section{MATERIALS AND METHODS}

\section{Geographical ranges}

The geographical ranges of the 9 described Pterois species were extracted from 2 unpublished data- 
bases, one compiled by R. Myers (Coral Graphics) and the other by the Institute for Research and Development, Nouméa Center. These 2 databases are constructed upon data from 110 sampling sites across the Indo-Pacific. The proportions (relative to the total number of species) of Scorpaenidae (the family of lionfish) and other piscivore species were extracted from the same databases for the IndoPacific, and from a similar database for the Atlantic (Halpern \& Floeter 2008).

\section{Underwater population estimates}

Population-density data came from a literature search and from previously unpublished observations. The literature search, which was based on the keyword 'Pterois', considered both indexed literature (as available through http://thomsonreuters. com/products_services/science/science_products/a-z/ web_of_science/) and non-indexed literature (available through search engines such as Google-Scholar, Google or Yahoo), the search being limited to the Indo-Pacific region. Data from the literature were gathered from both the Pacific and Indian Oceans (Table 1).

Two types of previously unpublished observations were compiled. These were (1) general censuses not specifically aimed at lionfishes, and (2) censuses specifically targeting lionfishes. General-census data were gathered from a large number of field surveys conducted from East Africa eastward to the Marquesas Islands and Rapa. Only surveys counting 'all species' of reef fishes were included. Densities were converted into fish $\mathrm{ha}^{-1}$ when the sampled area was available. We examined more than 10000 transects covering $>268$ ha. Our area spanned 57 islands or nations in the Pacific and 8 nations in the Indian

Table 1. Pterois spp. Number of lionfish observed and their densities in the Indo-Pacific based on published visual censuses. Only data based on 'total counts' (i.e. counts recording all or most observed species) are reported

\begin{tabular}{|c|c|c|c|c|}
\hline Region & Species & $\begin{array}{l}\text { No. lionfish } \\
\text { observed }\end{array}$ & $\begin{array}{l}\text { Density } \\
\left(\text { ind. } \mathrm{ha}^{-1} \text { ) }\right.\end{array}$ & Reference \\
\hline \multicolumn{5}{|l|}{ Pacific Ocean } \\
\hline $\begin{array}{l}\text { Middleton \& Elizabeth Reef } \\
\text { (SE Australia) }\end{array}$ & P. volitans & 2 & 2.4 & Oxley et al. (2004) \\
\hline $\begin{array}{l}\text { Millenium atoll } \\
\text { (Kiribati East) }\end{array}$ & Pterois spp. & 0 & 0 & Barott et al. (2010) \\
\hline Guam & Pterois spp. & 0 & 0 & Amesbury et al. (1999) \\
\hline Midway & P. sphex & $<5$ & & Schroeder \& Parrish (2006) \\
\hline Hawaii & P. sphex & 0 & 0 & Beets et al. (2010) \\
\hline Lord Howe (SW Pacific) & P. volitans & 9 & 2.7 & Valentine et al. (2008) \\
\hline Kermadec (SW Pacific) & P. volitans & 2 & prob. $\sim 7.4$ & Cole et al. (1992) \\
\hline Brunei & Pterois sp. & 1 & 1.1 & Chou et al. (1992) \\
\hline Taiwan & P. volitans & 1 & 2.2 & Chen et al. (2004) \\
\hline Seribu (Indonesia) & P. volitans & 8 & 2.4 & Suharsono et al. (1996) \\
\hline Moorea (Polynesia) & $P$. radiata & 2 & 0.9 & Lecchini et al. (2006) \\
\hline Rongelap (Marshall Is.) & Pterois spp. & 0 & 0 & Pinca et al. (2002) \\
\hline 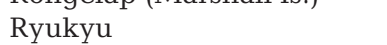 & P. antennata & 3 & 8.9 & Nakamura \& Sano (2004) \\
\hline Peninsular Malaysia & Pterois spp. & 0 & 0 & Harborne et al. (2000) \\
\hline Kiritimati (Line Is.) & Pterois spp. & 0 & 0 & Sandin et al. (2008) \\
\hline Yap (W Micronesia) & Pterois spp. & 0 & 0 & Smith \& Dalzell (1991) \\
\hline \multicolumn{5}{|l|}{ Indian Ocean } \\
\hline \multirow{3}{*}{ Reunion (SW Indian) } & P. antennata & 18 & 3.6 & Letourneur (1996b) \\
\hline & P. miles & 31 (out of 43200 fishes) & 6.2 & Letourneur et al. (2008) \\
\hline & P. antennata & 21 (out of 20324 fishes) & 16.7 & Letourneur (1998) \\
\hline Mauritius (SW Indian) & P. miles & 5 (out of 44000 fishes) & 3 & $\begin{array}{l}\text { Adjeroud et al. (1998) } \\
\text { Graham et al. (2007) }\end{array}$ \\
\hline Mauritius & P. miles & 3 & 2.5 & Chinea et al. (2001) \\
\hline Mayotte (SW Indian) & P. antennata & 1 (out of 4340 fishes) & 2.8 & Letourneur (1996a) \\
\hline Natal & Pterois spp. & & 0.3 to 6 & Berry et al. (1982) \\
\hline \multirow[t]{2}{*}{ Red Sea (Egypt) } & P. miles & 5 & 20.8 & Alter et al. (2008) \\
\hline & $P$. radiata & 3 & 12.5 & \\
\hline Red Sea & P. miles & 80 & prob. $>20$ & Fishelson (1997) \\
\hline
\end{tabular}


Ocean. A variety of underwater visual census (UVC) methods was used (Table S1 in the Supplement at www.int-res.com/articles/suppl/m446p189_supp.pdf). Transects were 25 or $50 \mathrm{~m}$ long and fish were counted within 2 to $5 \mathrm{~m}$ wide belts along these transects. These surveys were not specifically designed to census lionfish, but were intended to count as many species as possible. The observers did not conduct intensive searches in holes, crevices or under ledges, where lionfish tend to hide during daytime in the Indo-Pacific. The second kind of surveys, lionfish-specific censuses, were characterized by, first, their focused target (only Pterois spp. were recorded), and second, their methods: observers searched all holes, crevices and ledges within $5 \mathrm{~m}$ to each side of the transect line. The length of transects was different for each team, ranging from 50 to $500 \mathrm{~m}$ (see Table 3). Some of these lionfish-specific censuses, called Type 1 transects, were performed in habitats chosen at random within the reefs of a region, whereas the others, Type 2 transects, were performed in habitats specifically selected for their reported abundance of Pterois spp. Type 1 transects therefore provided an indication of the overall density of Pterois spp., whereas Type 2 transects were expected to yield an upper estimate, or maximum density, of Pterois spp.

\section{Fish catches}

We employed a variety of methods at New Caledonia and Chesterfield Islands (Table S2 in the Supplement) to capture lionfish, including trawls (shrimp and fish trawl), rotenone, gill nets, and fyke nets. Shrimp trawl nets had a $14 \mathrm{~m}$ long head-rope and a $2 \mathrm{~cm}$ cod-end mesh. Trawling speed was 2.3 knot, and tow duration was $33 \mathrm{~min}\left(1.2\right.$ ha tow $\left.^{-1}\right)$. Fish trawl nets had an $18 \mathrm{~m}$ long head-rope, a $2 \mathrm{~cm}$ codend mesh; trawling speed was 3 knot, and tow duration was $20 \mathrm{~min}\left(1.4\right.$ ha tow $\left.{ }^{-1}\right)$. Tow depth was between 4 and $83 \mathrm{~m}$. Trawls were run over soft bottoms where large sponges (e.g. Ircinia spp.), small coral heads, and at times branched Acropora coral fields were present, areas potentially inhabited by lionfish. Rotenone was applied at stations established mainly on coral reefs and sometimes on algae beds, both from 0 to $15 \mathrm{~m}$ depth. Gill nets and fyke nets were set along the shoreline, usually near mangroves or estuaries. On each station 3 gill nets were set in a row, with, sequentially, a mesh size of 30,50 and $75 \mathrm{~mm}$. Each net was $75 \mathrm{~m}$ long and $4 \mathrm{~m}$ high. Fyke nets had a $50 \mathrm{~m}$ leading net and a 3-way chamber with a cod-end mesh of $10 \mathrm{~mm}$. Soak time was $2 \mathrm{~h}$ for the gill nets and $12 \mathrm{~h}$ for the fyke nets. Both gill nets and fyke nets were set perpendicular to the shoreline; gill nets were set at high tide. The catchability of lionfish by trawls or rotenone is unknown (but see Kulbicki \& Wantiez 1990), yet is assumed to be very high, as these fish swim fast only in short bursts and tend to stay motionless when confronted, relying on cryptic behavior and their venomous spines for defense (Morris \& Whitfield 2009).

\section{Detectability}

Given that lionfish can be highly secretive within the reef framework, a major question arises regarding detectability during visual surveys. We addressed this issue by means of 3 methods. First, the densities observed during UVCs were compared to the densities obtained from rotenone stations in the same habitats and regions (rotenone stations being $<100 \mathrm{~m}$ from UVC stations) because rotenone captures most fish in an area (Ackerman \& Bellwood 2002). Second, the detection curves derived from 'distance sampling' (Buckland et al. 2001) were compared for all species combined, for lionfishes alone, and for another cave dwelling genus, Myripristis spp. In this method, the observer estimates the perpendicular distance between any observed fish or group of fish and the transect line (Labrosse et al. 2001). These distance distributions are used to estimate densities and to yield information on how objects are detected as the distance of observation increases (Buckland et al. 2001). This is a common method for evaluating reef-fish detectability (Kulbicki 1998, Kulbicki \& Sarramégna 1999, Kulbicki et al. 2010, Bozec et al. 2011). Distance sampling was performed on 7209 transects in the South Pacific (Table S1 in the Supplement). Third, within the same study location, the densities obtained from all-species transects were compared to densities from Type 1 UVC transects that specifically targeted Pterois spp.

\section{Larvae and new-settler samples}

Fish larvae were collected during several programs in the Indo-Pacific, and by 2 methods: light-traps and crest-nets. Light-traps (Doherty 1987) were set near reefs, at from 2 to $4 \mathrm{~m}$ below the surface, at night. Soaking time was usually from 2 to $6 \mathrm{~h}$. Crest nets (Dufour et al. 1996) were set on the reef crest, just behind the surf zone. They were usually set for sev- 
eral days, larvae being retrieved from the cod end twice a day. In some of these programs lionfish larvae were counted, thus yielding information on the relative abundance of these species. Similarly, by means of various recruitment surveys, reef fish were sampled near the time of settlement, generating some information on the relative abundance of settlementstage lionfish.

\section{Statistical analyses}

We used a generalized linear model (GLMz: backward and stepwise; error distribution: normal; link function: power) to test the potential influence of several large-scale factors on Pterois densities. These densities were log-transformed to normalize their distributions and reduce variance. The factors tested were (1) distance to the biodiversity center, taken as Indonesia at $107^{\circ} \mathrm{E}$ on the equator (Bellwood \& Meyer 2009) and log-transformed; (2) latitude, absolute value; (3) hemisphere (north or south); (4) sea surface temperature (SST; annual mean at the regional level; Locarnini et al. 2006); (5) ocean and coast type (island or continent) and (6) the firstdegree interactions of all categorical factors. A GLM tested whether the density of Pterois was a function of regional diversity in terms of (1) total species richness, taken as the total number of species known in each region; (2) piscivore regional richness, taken as the number of reef-fish species known to feed on fish within each region; (3) medium-size-piscivore (from 10 to $40 \mathrm{~cm}$, the same size-class as lionfish) regional richness; (4) Scorpaenidae regional richness, taken as the number of reef-dwelling scorpaenid species within each region; and (5) Pterois regional richness. No interaction was tested, as all these factors were considered to be continuous variables.

\section{RESULTS AND DISCUSSION}

\section{Geographical distribution}

Most Pterois have a wide geographical distribution (Fig. 1), although 2 species, $P$. sphex and $P$. andover, have restricted ranges (Fig. 1). P. volitans, the primary species invading western Atlantic and Caribbean coral reefs, is restricted to the Pacific Ocean, unlike $P$. antennata and $P$. radiata, which occur throughout the entire Indo-Pacific. $P$. miles (see Schultz 1986, Kochzius et al. 2003 for the status of this species), the second invasive species, presently restricted to the east coast of the USA (Freshwater et al. 2009), has a native range restricted to the Indian Ocean. The ranges of $P$. volitans and $P$. miles overlap in the Indonesian region (Fig. 1), but the precise boundaries of this overlap are at present not well defined. $P$. volitans has the most southern range limit, being reported at $34^{\circ} \mathrm{S}$, near northern New Zealand. $P$. lunulata and $P$. volitans have the northernmost range, being found off South Korea $\left(35^{\circ} \mathrm{N}\right)$. Both regions have a mean $\mathrm{SST}$ of $19^{\circ} \mathrm{C}$ and a minimal average winter temperature of $14^{\circ} \mathrm{C}$ (Locarnini et al. 2006). The number of Pterois species per region varies from 2 in the south Pacific and around Hawaii to 8 in the western Pacific (Table 2). The proportion of Scorpaenidae and of piscivore species to the regional reef fish assemblage (from 1.8 to $3.4 \%$ and from 14 to $21.6 \%$ respectively) does not vary substantially across the Indo-Pacific (Table 2).

\section{Densities on reefs}

Despite a large sampling effort ( $>3.6$ million fish counted on $>10000$ transects), only 64 lionfish were detected during the general visual censuses in the Pacific Ocean. Pterois volitans was the most commonly observed species among lionfishes (Tables 1 \& 3). We observed an average density of 0.17 Pterois ind. $\mathrm{ha}^{-1}$ for the entire Pacific, yet densities varied considerably among regions, and, in many regions, no lionfish were detected. The highest densities were detected on the limits of the geographical range of these species, with 5.0 fish $\mathrm{ha}^{-1}$ in the Marquesas $\left(8^{\circ} \mathrm{S}\right)$ and 7.2 fish $\mathrm{ha}^{-1}$ at Rapa $\left(27^{\circ} \mathrm{S}\right)$. The relative density (Pterois ind. per million fish) ranged from 0 in many locations to 120 at Rapa, with an average value of 17 for the entire Pacific (Table 3).

Censuses specifically targeting lionfish in the Pacific always detected Pterois spp. at from 2.7 to 9 fish ha ${ }^{-1}$ based on Type 1 transects, and from 6.4 to 32.9 fish ha ${ }^{-1}$ for Type 2 transects (Table 3 ). All these focused transects were performed in Micronesia and the Philippines.

The number of lionfish detected by all-species transects in the Indian Ocean was of the same order of magnitude (61 fish) as in the Pacific, but the sampling effort was far lower (<220 000 fish over 389 transects). Lionfish were observed in every study, except at the Glorieuses Islands (Mozambique Channel), and there was little variation among locations (Tables 1 \& 3). The highest densities were observed in the northern Red Sea (Egypt and Israel), with estimates of $>20$ Pterois ind. ha ${ }^{-1}$. On average, the density of Pterois in 
Table 2. Pterois spp. Species richness of reef fishes by region throughout the Indo-Pacific and the Atlantic. Medium piscivores: 10-40 cm total length. Pterois density values corrected for detectability (see 'Materials and methods: Detectability'). See Fig. 3 for Indo-Pacific regional boundaries. -: no data; I: invader

\begin{tabular}{|c|c|c|c|c|c|c|c|c|c|}
\hline \multirow[t]{2}{*}{ Region } & \multirow{2}{*}{$\begin{array}{c}\text { Total } \\
\text { species }\end{array}$} & \multicolumn{2}{|c|}{ Pterois spp. } & \multicolumn{2}{|c|}{ Scorpaenidae } & \multicolumn{2}{|c|}{ All piscivores } & \multicolumn{2}{|c|}{ Medium piscivores } \\
\hline & & $\mathrm{n}$ & $\mathrm{n} \mathrm{ha}^{-1}$ & $\mathrm{n}$ & $\%$ & $\mathrm{n}$ & $\%$ & $\mathrm{n}$ & $\%$ \\
\hline \multicolumn{10}{|l|}{ Indo-Pacific } \\
\hline West Indian (WI) & 1395 & 5 & 29.6 & 34 & 2.4 & 265 & 19 & 89 & 6.4 \\
\hline NW-Indian (NWI) & 1869 & 6 & 177 & 42 & 2.2 & 335 & 17.9 & 123 & 6.6 \\
\hline SW-Indian (SWI) & 1496 & 5 & 28 & 39 & 2.6 & 284 & 19 & 87 & 5.8 \\
\hline Mascareignes (MAS) & 1310 & 4 & 64 & 38 & 2.9 & 244 & 18.6 & 91 & 6.9 \\
\hline Central Indian (CI) & 2001 & 5 & 16.8 & 41 & 2 & 339 & 16.9 & 132 & 6.6 \\
\hline East Indian (EI) & 2581 & 7 & - & 46 & 1.8 & 406 & 15.7 & 165 & 6.4 \\
\hline China Sea-Philippines (CP) & 3361 & 5 & 6.2 & 90 & 2.7 & 506 & 15.1 & 228 & 6.8 \\
\hline Hawaii & 649 & 2 & 4 & 26 & 4 & 140 & 21.6 & 53 & 8.2 \\
\hline Indonesia-Malaysia (IND) & 3459 & 7 & 10.8 & 72 & 2.1 & 491 & 14.2 & 223 & 6.4 \\
\hline Melanesia (MEL) & 2054 & 3 & 0.2 & 47 & 2.3 & 305 & 14.8 & 124 & 6 \\
\hline Micronesia (MIC) & 1792 & 3 & 0.6 & 39 & 2.2 & 253 & 14.1 & 99 & 5.5 \\
\hline North Polynesia (NPOL) & 705 & 3 & 0 & 16 & 2.3 & 129 & 18.3 & 47 & 6.7 \\
\hline NW Pacific (NWP) & 2794 & 4 & 44.4 & 79 & 2.8 & 459 & 16.4 & 202 & 7.2 \\
\hline South Polynesia (SPOL) & 1079 & 3 & 13.5 & 32 & 3 & 190 & 17.6 & 80 & 7.4 \\
\hline South Pacific (SP) & 1024 & 2 & 39.4 & 31 & 3 & 170 & 16.6 & 64 & 6.3 \\
\hline SW Pacific (SWP) & 2262 & 7 & 2.2 & 78 & 3.4 & 353 & 15.6 & 142 & 6.3 \\
\hline West Pacific (WP) & 3146 & 8 & 0 & 79 & 2.5 & 439 & 14 & 194 & 6.2 \\
\hline \multicolumn{10}{|l|}{ Atlantic Ocean } \\
\hline Carolinian & 441 & I & I & 14 & 3.2 & 40 & 9.1 & 17 & 3.9 \\
\hline West Caribbean-Florida & 750 & $\mathrm{I}$ & I & 20 & 2.7 & 48 & 6.4 & 18 & 2.4 \\
\hline East Caribbean & 734 & I & I & 20 & 2.7 & 48 & 6.5 & 18 & 2.5 \\
\hline NE Brazil & 388 & - & - & 14 & 3.6 & 37 & 9.5 & 15 & 3.9 \\
\hline SE Brazil & 379 & - & - & 11 & 2.9 & 39 & 10.3 & 14 & 3.7 \\
\hline
\end{tabular}

the Indian Ocean was 3.6 ind. ha ${ }^{-1}$, which is 13 times higher than in the Pacific. Similarly the relative density of Pterois was 343 ind. per million fish, which is 20 times greater than in the Pacific.

Reef censuses targeting Indian Ocean lionfish irrespective of habitat (Type 1 transects) showed densities of 36 Pterois ind. ha ${ }^{-1}$, which is 4 to 13 times higher than the results of censuses conducted by similar methods in the Pacific (Table 3). Censuses targeting Indian Ocean habitats known to harbor lionfish (Type 2 transects) showed very high densities of 200 Pterois ind. ha ${ }^{-1}$, which is 6 to 31 times higher than what was shown in the Pacific using similar methods.

Unfortunately, many of the unpublished observations for the Indian Ocean recorded Pterois at the genus level, which does not permit an evaluation of which species are most abundant. However, from the literature (Table 1), from the unpublished work of P. Chabanet, and from surveys by Darling et al. (2011), a tentative pattern emerges for the Indian Ocean (Tables 1 \& 3): $P$. miles and P. antennata exhibit the highest densities, with P.radiata displaying lower densities. Other species ( $P$. mombasae, $P$. russeli) that occur in the Indian Ocean (Fig. 1) were not detected in these UVCs.

\section{Densities in other habitats}

A total of 641000 fish were captured in the compiled fishery catches. As in UVCs, very few Pterois (51 ind.; 73 ind. per million fish) were caught by fishing methods (Table 4). Shrimp trawls that sampled waters at depths mainly between 10 and $30 \mathrm{~m}$ caught the largest numbers (Table S2 in the Supplement). The highest densities were deduced from trawl catches on seafloors 10 to $20 \mathrm{~m}$ deep (0.68 ind. ha ${ }^{-1}$ ), followed by areas $<10 \mathrm{~m}$ deep ( 0.37 ind. ha ${ }^{-1}$ ). The deepest recorded catch was at $75 \mathrm{~m}$ (and the deepest trawl was $83 \mathrm{~m}$ ). These densities are of the same magnitude as those recorded from UVCs (Tables 1 \& 3) in the same regions. Pterois spp. has also been reported in trawl surveys from several other locations in the Pacific, reaching at times fairly high frequencies. In the Arafura Sea, P. russeli was reported in 13 out of 206 trawls and P. volitans once in 206 trawls (Ramm 1997). P. volitans occurred in $0.02 \%$ of the trawls in the Kimberley region of NW Australia (Newman et al. 2008), and Pterois spp. accounted for $0.015 \%$ of experimental trawl catches in Sarawak, Malaysia (Rumpet et al. 1999). Similar findings have been reported in the Indian Ocean, including the presence of Pterois 
Table 3. Pterois spp. Densities of lionfish and related data based on previously unpublished underwater visual censuses. For targeted counts, Type 1: censuses targeting Pterois spp. but with no a priori selection of habitat; Type 2: censuses targeting both Pterois spp. and habitats known to harbor Pterois spp. Team 1: M. Hixon \& J. Beets; Team 2: E. Darling \& J. K. O'Leary; Team 3: K. Cure \& J. McIlwain. NA: not available

\begin{tabular}{|c|c|c|c|c|c|c|c|c|c|c|}
\hline \multirow[t]{2}{*}{ Region } & \multirow{2}{*}{$\begin{array}{l}\text { No. islands/ } \\
\text { nations }\end{array}$} & \multirow{2}{*}{$\begin{array}{c}\text { No. of } \\
\text { transects }\end{array}$} & \multirow{2}{*}{\multicolumn{2}{|c|}{$\begin{array}{c}\text { Area } \\
\text { covered (ha) }\end{array}$}} & \multirow{2}{*}{\multicolumn{2}{|c|}{$\begin{array}{c}\text { No. of all fish } \\
\text { observed }\end{array}$}} & \multicolumn{4}{|c|}{ - Pterois ind. } \\
\hline & & & & & & & $\mathrm{n}$ & $\mathrm{n} \mathrm{ha}^{-1}$ & & million $^{-1}$ \\
\hline \multicolumn{11}{|l|}{ Pacific Ocean } \\
\hline Fiji & 3 & 528 & \multicolumn{2}{|c|}{13.2} & \multicolumn{2}{|c|}{192732} & 1 & 0.08 & & 5.2 \\
\hline Society & 2 & 600 & \multicolumn{2}{|c|}{4.1} & \multicolumn{2}{|c|}{142383} & 2 & 0.48 & & 14 \\
\hline Tuamotu & 13 & 844 & \multicolumn{2}{|c|}{16.0} & \multicolumn{2}{|c|}{253591} & 4 & 0.25 & & 16 \\
\hline Indonesia & 1 & 185 & \multicolumn{2}{|c|}{9.3} & \multicolumn{2}{|c|}{ NA } & 0 & 0 & & 0 \\
\hline Rapa & 1 & 28 & \multicolumn{2}{|c|}{0.28} & \multicolumn{2}{|c|}{16679} & 2 & 7.1 & & 120 \\
\hline Marquesas & 4 & 157 & \multicolumn{2}{|c|}{0.8} & \multicolumn{2}{|c|}{35736} & 4 & 5.0 & & 112 \\
\hline New Caledonia & 5 & 6034 & \multicolumn{2}{|c|}{150.8} & \multicolumn{2}{|c|}{2463872} & 47 & 0.31 & & 19 \\
\hline New Caledonia & 3 & 306 & \multicolumn{2}{|c|}{15.4} & \multicolumn{2}{|c|}{186096} & 4 & 0.26 & & 22 \\
\hline Palau & 1 & 78 & $0 . C$ & & 1072 & & 0 & 0 & & 0 \\
\hline Samoa & 8 & 365 & 6.5 & & 7161 & & 0 & 0 & & 0 \\
\hline Solomon Islands & 13 & 330 & 4.1 & & 16204 & & 0 & 0 & & 0 \\
\hline Tonga & 3 & 619 & 15.5 & & 15947 & & 0 & 0 & & 0 \\
\hline Wallis \& Futuna & 2 & 130 & 4.1 & & $\mathrm{~N}$ & & 0 & 0 & & 0 \\
\hline Total Pacific & 57 & 10204 & 241.1 & & $\sim 369500$ & & 64 & 0.27 & & 17 \\
\hline Indian Ocean & & & & & & & & & & \\
\hline Glorieuses Is. & 1 & 39 & $0 . c$ & & 2975 & & 0 & 0 & & 0 \\
\hline Geyser Bank & 1 & 48 & 0.7 & & 2698 & & 4 & 5.2 & & 148 \\
\hline Kenya & 1 & 132 & 6.6 & & 4312 & & 25 & 3.8 & & 580 \\
\hline Madagascar & 1 & 59 & $2 . c$ & & 2220 & & 5 & 1.7 & & 225 \\
\hline Maldives & 1 & 21 & 1.2 & & 2703 & & 3 & 2.5 & & 111 \\
\hline & & 24 & 1.2 & & 1405 & & 2 & 1.7 & & 142 \\
\hline Mayotte & 1 & 15 & 0.7 & & 1604 & & 6 & 8.0 & & 374 \\
\hline Mozambique & 1 & 25 & 1.2 & & 1713 & & 6 & 4.8 & & 350 \\
\hline Tanzania & 1 & 26 & 1.3 & & 2250 & & 6 & 3.6 & & 267 \\
\hline Total Indian & 8 & 389 & 17. & & $\sim 21880$ & & 61 & 3.59 & & 343 \\
\hline Targeted counts & $\begin{array}{l}\text { No. of } \\
\text { sites }\end{array}$ & $\begin{array}{c}\text { Area covered } \\
\text { (ha) }\end{array}$ & $\begin{array}{c}\text { P. an } \\
\mathrm{n}\end{array}$ & $\begin{array}{l}\text { ennata } \\
\mathrm{n} \mathrm{ha}^{-1}\end{array}$ & & $\begin{array}{l}\text { adiata } \\
\mathrm{n} \mathrm{ha}^{-1}\end{array}$ & $\begin{array}{c}\text { P. voli } \\
\mathrm{n}\end{array}$ & $\begin{array}{l}\text { ans/miles } \\
\mathrm{n} \mathrm{ha}^{-1}\end{array}$ & & $\begin{array}{l}\text { Pterois } \\
\mathrm{n} \mathrm{ha}^{-1}\end{array}$ \\
\hline Type 1 & & & & & & & & & & \\
\hline Pohnpei (Team 1) & 10 & 3.68 & 6 & 1.63 & 1 & 0.27 & 3 & 0.81 & 10 & 2.71 \\
\hline Guam (Team 1) & 14 & 7.54 & 32 & 4.24 & 19 & 2.51 & 3 & 0.39 & 54 & 7.16 \\
\hline Cebu (Team 1) & 3 & 6.1 & 44 & 7.21 & 0 & 0 & 11 & 1.8 & 55 & 9.01 \\
\hline Kenya (Team 2) & 6 & 1.0 & 19 & 19.0 & 9 & 9.0 & 8 & 8.0 & 36 & 36.0 \\
\hline Total Type 1 & 33 & 18.32 & 90 & 4.91 & 29 & 1.58 & 36 & 1.96 & 155 & 8.46 \\
\hline Type 2 & & & & & & & & & & \\
\hline Guam (Team 3) & 23 & 20.95 & 76 & 3.62 & 7 & 0.33 & 51 & 2.43 & 134 & 6.39 \\
\hline Negros (Team 3) & 16 & 6.35 & 89 & 14.01 & 0 & 0 & 112 & 17.63 & 201 & 31.65 \\
\hline Bohol (Team 3) & 9 & 3.86 & 57 & 14.76 & 0 & 0 & 70 & 18.13 & 127 & 32.9 \\
\hline Kenya (Team 2) & 1 & 0.11 & 8 & 67.6 & 0 & 0 & 14 & 110.5 & 22 & 178.1 \\
\hline Total Type 2 & 49 & 31.27 & 230 & 7.35 & 7 & 0.22 & 247 & 7.89 & 484 & 15.47 \\
\hline
\end{tabular}

in experimental trawls in the northern Red Sea (ElGanainy et al. 2005) or among the discarded fish in the Sri Lanka trawl fishery (Fernando 1972).

No Pterois were caught or observed in or near mangroves in New Caledonia despite the use of sev- eral collection or observation methods (gill nets, fyke nets, rotenone, UVCs). Pterois has been reported from mangroves in Fiji and Vanuatu but with no indication on their abundance (Thollot 1993). Lionfishes have also been reported in nearshore areas of the 
Table 4. Pterois spp. Depth distribution of catch size and fish mass of lionfish in New Caledonia. n: no. of ind. caught; Wt: average weight per ind. in grams. -: no data

\begin{tabular}{|c|c|c|c|c|c|c|c|c|c|c|c|c|c|c|}
\hline \multirow{2}{*}{$\begin{array}{l}\text { Depth } \\
\text { (m) }\end{array}$} & \multirow{2}{*}{$\begin{array}{c}\text { Area } \\
\text { covered (ha) }\end{array}$} & \multicolumn{2}{|c|}{ P. antennata } & \multicolumn{2}{|c|}{ P. lunulata } & \multicolumn{2}{|c|}{ P. radiata } & \multicolumn{2}{|c|}{ P. volitans } & \multicolumn{2}{|c|}{ Pterois sp. } & \multirow[b]{2}{*}{ Total $n$} & \multirow{2}{*}{$\begin{array}{r}\text { Pterois } \\
\mathrm{n} \mathrm{ha}^{-1}\end{array}$} & \multirow[b]{2}{*}{$\mathrm{n}$ million ${ }^{-1}$} \\
\hline & & $\mathrm{n}$ & $\mathrm{Wt}$ & $\mathrm{n}$ & $\mathrm{Wt}$ & $\mathrm{n}$ & Wt & $\mathrm{n}$ & Wt & $\mathrm{n}$ & $\mathrm{Wt}$ & & & \\
\hline $0-10$ & 158 & - & & 1 & 280 & 4 & 2 & 7 & 120 & 16 & 19 & 28 & 0.16 & 87 \\
\hline $10-20$ & 66 & - & & 3 & 307 & 1 & 50 & 1 & 55 & 8 & 25 & 13 & 0.20 & 71 \\
\hline $20-30$ & 76 & - & & - & & - & & - & & - & & 0 & 0.00 & 0 \\
\hline $30-40$ & 86 & - & & - & & - & & - & & 1 & 10 & 1 & 0.01 & 25 \\
\hline $40-70$ & 97 & 1 & 25 & - & & - & & - & & - & & 1 & 0.01 & 41 \\
\hline$>70$ & 8 & 1 & 50 & - & & - & & - & & - & & 1 & 0.13 & 571 \\
\hline Total & 491 & 2 & 38 & 4 & 300 & 5 & 12 & 8 & 112 & 25 & 21 & 44 & 0.09 & 68 \\
\hline
\end{tabular}

Philippines (Pinto 1987), Indonesia (Weis \& Weis 2005), Thailand (Hajisamae \& Yeesin 2010) and northern Australia (Baker \& Sheppard 2006), but little information is available on their abundance in these habitats. Similar information is available for mangroves in the Indian Ocean, ranging from Egypt (El-Dawi 1997) to Tanzania and Zanzibar (Lugendo 2007), to Mozambique (Macnae \& Kalk 1962, de Boer et al. 2001, Gell \& Whittington 2002) and Madagascar (Ory 2008). The relative abundance of Pterois in some of the catches in these nearshore areas seems much greater than on reefs or soft bottoms. To compare with the UVC findings (Tables 1 \& 3) or catches on soft bottoms (Table 4), we transformed these values as Pterois ind. per million fish. In Mozambique, the relative abundances were 2205 ind. per million fish (de Boer et al. 2001); in Madagascar, 314 (Ory, 2008); in seagrass beds in Kenya, 1370 (de Troch et al. 1998); and in Egyptian mangroves, 'frequent' (ElDawi 1997). These numbers are of the same magnitude as reef-fish densities in the Indian Ocean (Tables 1 \& 3), and probably higher. Most of these inshore lionfishes seem to be juveniles, but published data are insufficient for determining the proportion.

\section{Detectability}

Different methods of estimating detectability of lionfish yielded similar results. First, densities obtained from rotenone stations (73 stations over a 1.45 ha area) on shallow reefs were higher $(6.2$ Pterois ind. ha ${ }^{-1}$ ) than in all-species UVCs, but similar to the densities observed in censuses specifically targeting lionfish in the Pacific (Table 3). The densities calculated from UVCs (204 transects over an area of $10.2 \mathrm{ha}_{\text {, }}$ ) in the same habitats sampled using rotenone was 0.89 ind. $\mathrm{ha}^{-1}$. The ratio of rotenone catch:UVC estimates was 6.96 .
Second, the frequency of lionfish sightings related to distance from the transect line (detection curve) decreased faster than for all species pooled (Fig. 2a), suggesting that lionfish are better detected at close range. $78 \%$ of the sightings occurring between 0 and $3 \mathrm{~m}$ of the transect line. The detection curve for lionfish was similar to that of Myripristis spp., a daytime cave-dwelling fish (Fig. 2b). Myripristis was abundant and frequent at rotenone stations. Assuming that nearly all Myripristis were caught at rotenone stations, this permitted a good estimate of actual density (rotenone) to observed densities (in nearby visual transects). However, because lionfish were uncommon, the ratio between actual density and observed densities are probably less accurate. The ratio of actual:observed was 5.70 for Myripristis and 6.96 for lionfish, suggesting that the detectability of these species is comparable.

Third, in Kenya (Table 1), the mean density obtained by all-species censuses was 3.8 Pterois ind. $\mathrm{ha}^{-1}$, whereas mean density obtained by Type 1 transects was of 36 Pterois ind. $\mathrm{ha}^{-1}$. This comparison yields a correction factor of 9.47 (36/3.8).

The average of these 3 independent estimates of detectability suggests a correction factor of approximately 8 , which means that on all-species transects only 1 Pterois would be detected for every 8 actually present.

\section{Larvae and new settlers}

Most of the information available on the relative abundance of lionfish larvae was from the Pacific Ocean, where lionfish larvae were rare in most cases (Table 5), and with the largest proportion being observed at Rangiroa (Lo Yat 2002; 331 ind. per million fish). There may be substantial interannual variation in the proportion of lionfish in the larval pool 

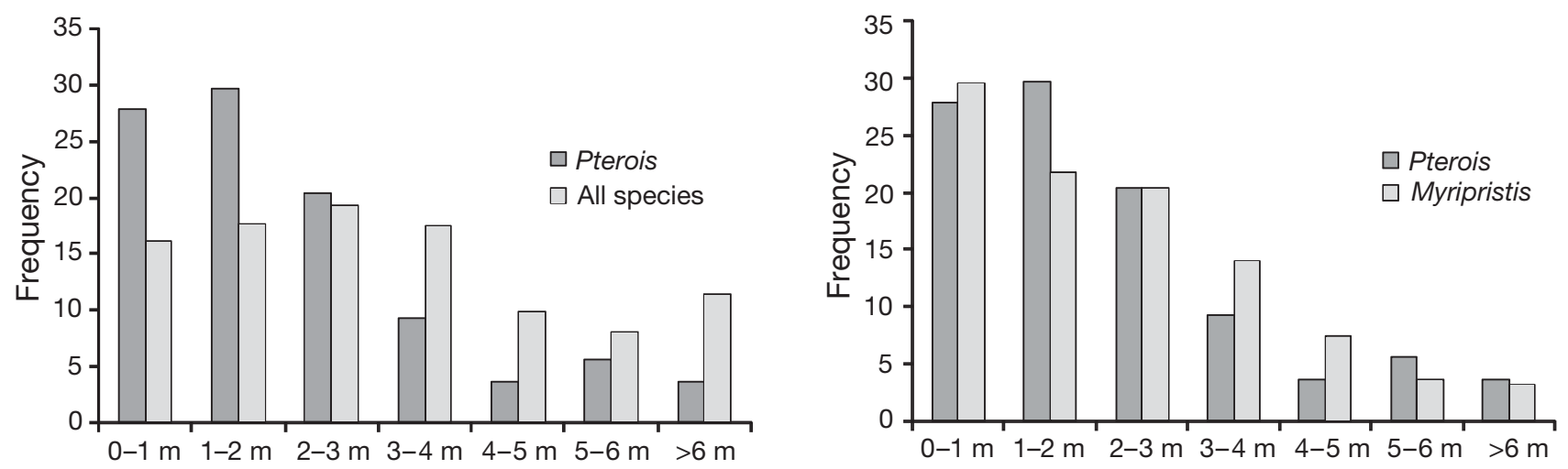

Fig. 2. Pterois spp. In the South Pacific, frequency of detection by distance from transect for (A) lionfish versus other species, where $G$-test is significant at $\mathrm{p}<0.0001$; and for (B) lionfish versus Myripristis, another cave-dwelling genus. where $G$-test is not significant at $\mathrm{p}=0.27$. For lionfish, $\mathrm{N}=54$ occurrences; for all other species together, $\mathrm{N}=457000$ occurrences; for Myripristis alone, $\mathrm{N}=1409$ occurrences

Table 5. Pterois spp. Abundance of lionfish among sampled settlement-stage reef-fish larvae and recently settled juvenile reef fish. FP: French Polynesia.

\begin{tabular}{|lcccll|}
\hline Region & $\begin{array}{c}\text { No. of } \\
\text { lionfish }\end{array}$ & $\begin{array}{c}\text { Total no. } \\
\text { of larvae }\end{array}$ & $\begin{array}{c}\text { Pterois/ } \\
\text { Scorpaenidae }\end{array}$ & Gear or method & Reference \\
\hline Tikehau (FP) & 0 & 19800 & - & Crest net & R. Galzin (unpubl.) \\
Rangiroa (FP) & 55 & 166124 & $1 / 200$ & Crest net & LoYat (2002) \\
Moorea (FP) & 0 & 4280 & - & UVC & COVARE (unpubl.) \\
& 5 & 7500 & $5 / 133$ & Crest net & Lecchini et al. (2006) \\
Wallis & 4 & 62610 & $4 / 30$ & Crest net & Juncker (2005) \\
Aitutaki (Cook Is.) & 2 & 13073 & $2 / 16$ & Crest net \& light trap & Malpot et al. (2008) \\
Rangiroa (FP) & 2 & 1158760 & $2 / 275$ & Crest net \& light trap & Malpot (2005) \\
Moorea (FP) & $(37)^{\mathrm{a}}$ & 31710 & - & Crest net & Riclet (1995) \\
New Caledonia & 0 & 11560 & - & UVC & Mellin (2008) \\
& 0 & 5420 & - & Trap \& seine & Carassou (2008) \\
New Caledonia & 1 & 109340 & $1 / 75$ & Light trap & Doherty \& Mcllwain (1996) \\
Great Barrier Reef & $(158)^{\mathrm{a}}$ & 56474 & - & Crest net & Kaunda-Arara et al. (2009) \\
Kenya & 0 & 750 & - & Light trap & Vermond et al. (2009) \\
Reunion & $(38)^{\mathrm{a}}$ & 15899 & - & Light trap & Durville et al. (2002) \\
& 1 & 984 & $1 / 29$ & Crest net & Mahafina et al. (unpubl.) \\
Madagascar & 1 & 4049 & - & Light trap & L. Vigliola (pers. comm.) \\
Dampier Archip. & 0 & 28535 & $0 / 4$ & Light trap & McIlwain (2003) \\
(W. Australia) & $(432)^{\mathrm{a}}$ & 89598 & - & Crest net & \\
Ningaloo Reef & & & & & \\
(W. Australia) & & & & & \\
aData for all Scorpaenidae & & & & \\
bJ. Mahafina, P. Chabanet, G. Lecaillon, J. P. Caminade, C. Ralijaona, J. Ferraris & \\
\hline
\end{tabular}

because, despite a large sampling effort, only 1 lionfish was captured at Rangiroa 3 yr after the original study (Malpot 2005). If one excludes the 2 largest catches of lionfish larvae in these studies (Lo Yat 2002, Riclet 1995), the proportion of lionfish among all larvae (9.3 ind. per million fish) is lower than for adult fish (17.8 ind. per million fish). Nonetheless, the order of magnitude of these estimates is the same. The few studies on larvae in the Indian Ocean do not list Pterois specifically, but do indicate the proportion of Scorpaenidae (Table 3). The proportion of Pterois larvae among Scorpaenidae larvae varied from $0.5 \%$ (Lo Yat 2002) to $12.5 \%$ (Malpot et al. 2008), with an unweighted average of $5.1 \%$.

\section{Effects of large-scale factors}

To compare all the observations in standardized form across different survey methods, a distribution map was constructed using a correction factor of 8 for normal surveys and of 1 for surveys specific to Pterois 
(Fig. 3). This approach revealed large differences in Pterois densities between the Pacific and Indian Oceans (Fig. 3). Pterois is generally rare over most of the central Pacific (Micronesia, Melanesia and the western part of Polynesia), with higher densities recorded in the Indian Ocean.

Using a GLMz, we tested the potential influence on Pterois densities (log-transformed) of distance to the biodiversity center, latitude, hemisphere, SST, ocean and coast type and the interactions of these variables (see Table S3 in the Supplement for details). This GLM indicated that several large-scale factors affect Pterois densities. Latitude was the most significant factor ( $\mathrm{p}<0.0001)$, with densities of Pterois spp. increasing with increasing latitude. Coast type was the second most important factor $(\mathrm{p}<0.005)$, with Pterois densities being higher in continental areas than around islands. The difference between Indian Ocean and Pacific Ocean densities (Indian Ocean densities being higher) was complex, as 2 interactions involving the factor 'Ocean' were significant: the 'Ocean $\times$ Hemisphere' interaction $(p<0.05)$ and the 'Ocean $\times$ Coast type' interaction $(p<0.001)$. The first interaction was due to higher relative values in the Southern Hemisphere for the Pacific Ocean than for the Indian Ocean. The second interaction was due to the greater decrease of Pterois densities in the Pacific as compared to the Indian Ocean as one proceeds from continental areas to islands. Distance to the biodiversity center also had a significant effect ( $\mathrm{p}<0.05)$, Pterois densities increasing with this distance. SST was not significant, but this factor was strongly correlated with latitude $(r=-0.86 ; \mathrm{N}=47$ ) and to a lower extent to hemisphere $(r=-0.39)$.

A GLM was used to test (see Tables S4 \& S5 in the Supplement for details) whether the density of Pterois was a function of regional species richness for the following levels: total richness, piscivore richness (all piscivores), medium-size-piscivore (from 10 to $40 \mathrm{~cm}$ ) richness, scorpaenid richness, and Pterois richness (Table 2). None of these factors proved significant.

\section{Effects of fishing on lionfishes}

Visual-transect data from the Indian Ocean (Kenya, Mozambique, Tanzania, Madagascar and Mayotte) were analyzed according to the status 'protected' (23 Pterois ind., 71700 fish, 242 transects) ver-

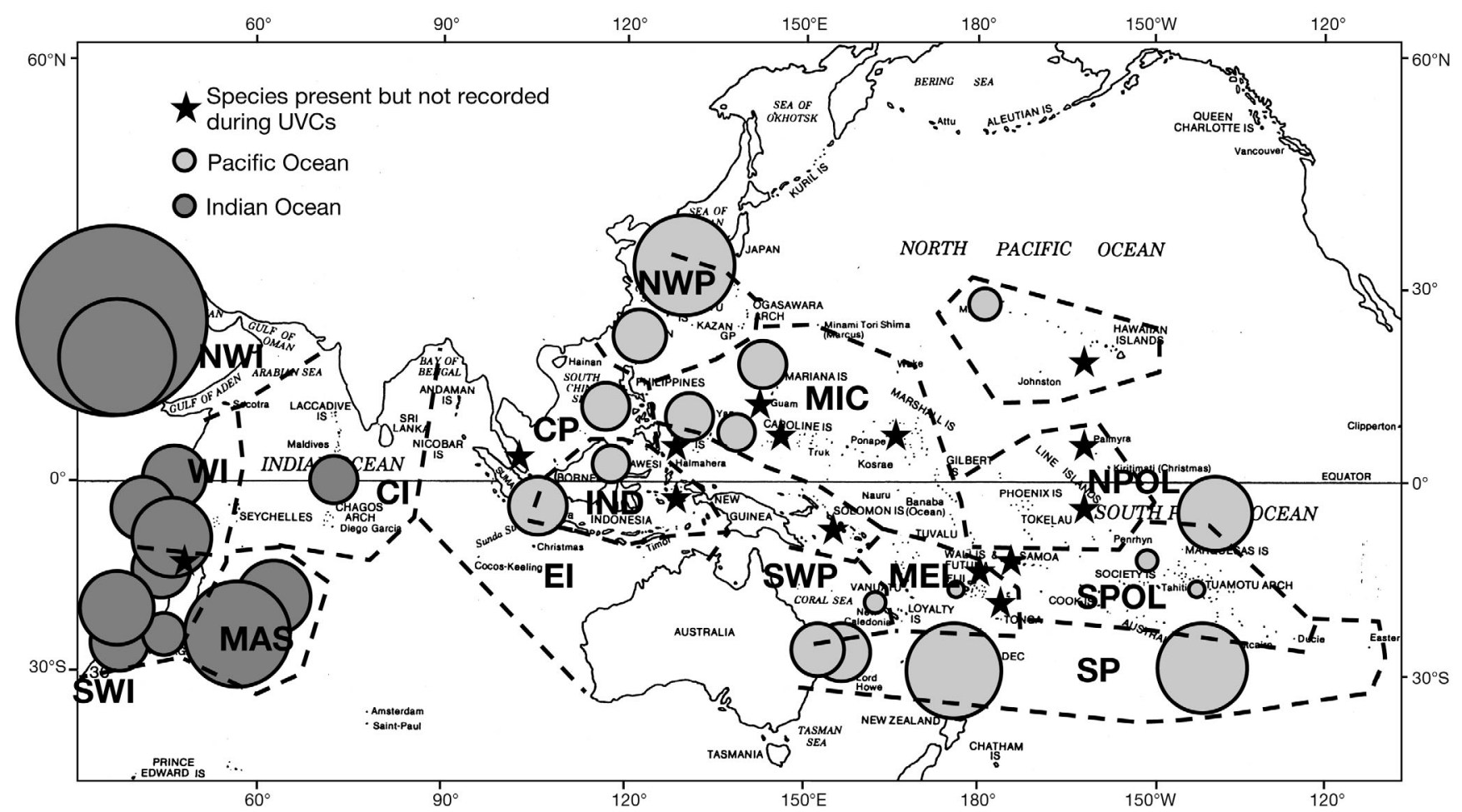

Fig. 3. Pterois spp. Geographical distribution of lionfish densities on Indo-Pacific coral reefs. Area of each circle is proportional to observed density. All densities (Tables 1 \& 3) corrected for detectability by a factor of 8 for non-specific surveys and by a factor of 1 for lionfish-specific surveys. Stars: underwater visual census (UVC) surveys where no Pterois were detected despite presence of these species in species checklists of these areas. See Table 2 for definition of regions 
sus 'unprotected' (27 Pterois ind., 63400 fish, 320 transects). Protected areas had significantly higher densities of fish (all species pooled; $107 \%$ increase in protected areas; F-test: p $<0.05$ for Kenya, Tanzania and Mozambique), but no protected-area effect could be detected for Pterois (9\% increase in protected areas). A similar analysis in New Caledonia, one that compared the densities observed in the harbor of Nouméa (8 Pterois ind., 499000 fish, 807 transects), where pollution and fishing are substantial, with densities from low-perturbation coastal areas (5 Pterois ind., 333000 fish, 374 transects), also indicated no significant differences in the density or relative abundance of Pterois $\left(\chi^{2}: \mathrm{p}=0.59\right)$.

\section{CONCLUSIONS}

Our macro-ecological approach examined the distribution of lionfish of the genus Pterois in their native Indo-Pacific range to facilitate comparisons with their invaded Atlantic range. We conclude that:

(1) Pterois is rare over most of its native range in the Indo-Pacific. Its average densities, even when corrected for detectability, are far less than densities observed in its invaded Atlantic range.

(2) The densities of Pterois are higher in the Indian Ocean than in the Pacific Ocean. It is noteworthy that, of the invasive species, $P$. volitans occurs in the Pacific and $P$. miles occurs in the Indian Ocean.

(3) The densities of Pterois are higher at the borders of its native range than in central regions, and higher on continental shelves than around islands.

(4) Pterois is found over a wide range of habitats in its native range, including coral reefs, soft substrates, algae and seagrass beds, mangroves and estuaries. It has been found in waters up to $75 \mathrm{~m}$ deep in its native range.

(5) The abundance ratios between settlementstage larvae and adults are similar across various locations in the Pacific, indicating broadly similar juvenile survival rates.

(6) There appears to be no correlation at the regional level between Pterois species richness or density with the species richness or density of other scorpionfishes or piscivores.

Pterois is rare in the Indo-Pacific and thus it is important to discuss problems linked to estimating its presence and abundance in its native range. Our analysis of detectability shows that these fish are not easily detected. In the Indo-Pacific, Pterois often hides in holes, crevices or under ledges during daytime and leaves shelters mainly at night, although
$P$. volitans may be found in the open during daytime (Cure 2011). This behavior may reduce Pterois detection by observers if a focused sampling protocol is not followed. Our UVC data suggest that, in the IndoPacific, only one Pterois ind. in 8 is detected by nonspecialized survey methods. In the absence of a similar analysis in the Atlantic, it is not possible to say whether a similar detection factor applies there. However, surveys in the Atlantic suggest that invasive Pterois are relatively conspicuous and easy to detect as they are frequently out of shelter and active during the day (Côté \& Maljković 2010), as confirmed by comparative observations in both native and invaded ranges (Darling et al. 2011, M. Hixon, J. Beets pers. obs.). Changes in behavior are documented for many species that have escaped their natural predators (Mittelbach 1986, Holway \& Suarez 1999, Sih et al. 2009). Even if the correction for detectability is applied, the estimated densities of Pterois in the Indo-Pacific remain much lower (average of 1.7 ind. ha ${ }^{-1}$ in the Pacific, 28.8 ind. ha ${ }^{-1}$ in the Indian Ocean) than their densities in the invaded regions (average of 100 ind. ha ${ }^{-1}$ in the Bahamas, Darling et al. 2011; to 400 ind. ha ${ }^{-1}$, Green \& Côté 2009, Morris \& Whitfield 2009). Such high population densities are common for invasive species (Sakai et al. 2001), especially during the early stages of their invasion.

These large differences in density between native and invaded range suggest that Pterois has undergone ecological release, escaping natural abiotic or biotic controls operative in its native Indo-Pacific range. These might include predation, disease and parasites, competition and limited dispersal. Examining the sources of ecological release is presently an active area of research. The ratio of settlement-stage to adult abundance at various locations in the Pacific suggests juvenile mortality rates that may not be substantially different from those of other reef fishes (Almany \& Webster 2006).

Anecdotal evidence is accumulating that several predatory species, in particular reef sharks and groupers, may occasionally feed on Pterois in the Atlantic (Mumby et al. 2011, M. Hixon pers. obs.), but no species in the Atlantic has yet been identified as targeting Pterois frequently enough to greatly restrain the invasion.

Does Pterois face much less competition in the Atlantic than in its native range? Lack of competition may be an important factor as Pterois lionfishes invade a range, since invaders often occupy previously vacant 'niche space' (sensu Cohen \& Stephens 1978). $P$. miles and $P$. volitans are mainly piscivorous 
(Albins \& Hixon 2008, Morris \& Akins 2009, Côté \& Maljković 2010, Muñoz et al. 2011), although juvenile lionfish also prey on invertebrates. Indirect indicators of interspecific competition used in this study showed no regional or local competitive factors. For example, no correlation was found between lionfish densities and the regional species richness of Pterois, other scorpaenids, or piscivore species in general (Table 2). In addition, at the local level, no differences in lionfish densities between fished areas and fisheries closures or between highly disturbed and undisturbed areas were found, suggesting that predation and competition have little or no effect. In the western Atlantic, the proportion of piscivores is nearly half that observed in the Indo-Pacific at the regional level, and the absolute number of piscivore species is also much lower in the Atlantic than in any region of the Indo-Pacific. On the other hand, the proportion of Scorpaenidae in the regional species pool of the Atlantic ( $3 \%$ ) is slightly higher than in the Indo-Pacific $(2.6 \%)$. Lastly, it should be noted that $P$. miles has been reported from the Mediterranean Sea as an invading Lessepsian species (Golani \& Sonin 1992), yet this species has so far remained at very low densities in its new range (Galil 2007). Consequently, predation and interspecific competition may not be major limiting factors for Pterois in the Indo-Pacific.

Limited dispersal and colonization of new habitats may influence the success of invading species. In their native range, lionfish are found not only on reefs but also in other habitats such as soft bottoms, seagrass beds and even mangroves. Our data show that in New Caledonia Pterois spp. are found on soft bottoms at population densities close to those observed on nearby reefs. They have also been observed on soft bottoms in many other Indo-Pacific regions at relatively high densities. Our results also show that Pterois has been observed near mangroves and estuaries in several Indo-Pacific regions, often in similar or even larger numbers than what is found on reefs. These results suggest that Pterois could become a frequent occupant of non-reef habitats in its invaded Atlantic range. For example, lionfishes have already been observed in seagrass beds and nonestuarine mangroves in the Bahamas (Barbour et al. 2010). Both seagrass beds and mangroves are important nursery habitats for a number of economically and ecologically important species in the Caribbean (Mumby et al. 2004, Verweij et al. 2006). The occupancy of these habitats also suggests that large expanses of non-reef areas may present no obstacle to the spread of lionfish in the Atlantic.
Pterois has been reported at $60 \mathrm{~m}$ depth and deeper (Froese \& Pauly 2010), a finding that is confirmed by trawl surveys (in which Pterois was caught at $75 \mathrm{~m}$ ), indicating the potential capacity of lionfish to disperse via deep waters; however, detailed data on their maximum depth is lacking. This finding is also confirmed in the Atlantic, where lionfish have been caught down to $99 \mathrm{~m}$ off the Carolinas (Meister et al. 2005) and observed from a submersible at $300 \mathrm{~m}$ in the Bahamas (M. O'Neil pers. comm.). Dispersal through deep water could allow invasive lionfish to pass the Amazon-Orinoco barrier, thereby expanding their southern range, as deep-water pathways have been demonstrated to be important in species distribution in the South Atlantic (e.g. Feitoza et al. 2005). The pelagic larval duration of Pterois in the Pacific (41 d for P. radiata, Lo Yat 2002; $40 \mathrm{~d}$ for $P$. volitans, Ruiz-Carus et al. 2006) is sufficient to ensure its dispersal within archipelagoes such as the Indonesian, Solomon Islands, Vanuatu or New Caledonia, where these fish remain uncommon. Pelagic larval duration of P. volitans in the Atlantic ranges from 20 to $35 \mathrm{~d}$ (average $26.2 d_{\text {i }}$ Ahrenholz \& Morris 2010). Thus the larval duration of this species is sufficient to ensure a wide and rapid establishment in the western Atlantic and Caribbean.

Beyond helping us to understand the potential mechanisms fostering this invasion, the present data on the distribution of lionfish in their native range may also be useful in predicting the potential evolution of this invasion. Densities of Pterois were higher at the boundaries of their native range, near the southern or northern limits of their ranges. In the absence of density data for the entire geographical range of Pterois spp. in the Indo-Pacific, this pattern should be interpreted with caution. Such an increase on the border of the geographical range of a species or genus contradicts the prevailing hypothesis that population abundance decreases at the limit of species range (Brown 1984). This pattern may indicate stronger (albeit unknown) limiting factors on lionfish density at the center of their geographical range than at the boundaries.

Our analyses also indicate that, in the IndoPacific, Pterois is found at higher densities over continental shelves than near islands. Habitat size and diversity is in general greater on continental shelves than on islands; this may favor higher connectivity and consequently higher densities of these habitat generalists over continental shelves. If this pattern emerges in the Atlantic after lionfish densities have stabilized, we would expect higher 
densities in the northern and southern parts of their new range and along the continental shelves as compared to islands (mainly Caribbean islands and the Bahamas).

It is difficult to estimate the ultimate impact of lionfish on native reef-fish assemblages in the Caribbean until their numbers have stabilized; it is also difficult to estimate whether the current high densities will stabilize or signify the first stage of an invasion process. The present densities of piscivorous fishes in the Caribbean are difficult to assess and may be heavily influenced by a long history of fishing. The Atlantic and Gulf Rapid Reef Assessment (AGRRA) database provides a first and probably crude estimate for the Caribbean (Marks 2007), with values ranging from $<100$ to $>881$ piscivores $\mathrm{ha}^{-1}$, with an average of 458 piscivores $\mathrm{ha}^{-1}$ (Table 6). Another source of data for the Atlantic (S.

Table 6. Pterois spp. Large-piscivore densities for Atlantic and South Pacific reefs. In Marks (2007) only transect data obtained by 'experienced' observers were retained

\begin{tabular}{|c|c|c|c|c|c|c|}
\hline \multirow[t]{2}{*}{ Region } & \multirow{2}{*}{$\begin{array}{c}\text { Area } \\
\text { covered } \\
\text { (ha) }\end{array}$} & \multirow{2}{*}{$\mathrm{n}$} & \multicolumn{2}{|c|}{ - Piscivores } & \multirow[t]{2}{*}{ Status } & \multirow[t]{2}{*}{ Source } \\
\hline & & & $\mathrm{n} \mathrm{ha} \mathrm{h}^{-1}$ & No. of species & & \\
\hline \multicolumn{7}{|l|}{ Atlantic: Caribbean } \\
\hline Bahamas & 2.544 & 1574 & 618 & 14 & & Marks (2007) \\
\hline Belize & 2.754 & 1554 & 564 & 14 & & Marks (2007) \\
\hline Bocas del Toro (Panama) & 0.624 & 410 & 657 & 10 & & S. Floeter et al. (unpubl.) \\
\hline Cayman Islands & 2.598 & 1217 & 468 & 13 & & Marks (2007) \\
\hline Cuba & 9.768 & 7548 & 772 & 15 & & Marks (2007) \\
\hline Dominican Republic & 0.948 & 79 & 83 & 5 & & Marks (2007) \\
\hline Dry Tortugas & 0.942 & 600 & 636 & 8 & & Marks (2007) \\
\hline Jamaica & 3.546 & 597 & 168 & 9 & & Marks (2007) \\
\hline Mexico & 2.256 & 837 & 371 & 12 & & Marks (2007) \\
\hline Netherlands Antilles & 1.764 & 718 & 407 & 9 & & Marks (2007) \\
\hline Panama & 2.586 & 832 & 321 & 12 & & Marks (2007) \\
\hline Puerto Rico & 1.044 & 251 & 240 & 10 & & Marks (2007) \\
\hline St. Vincent & 0.300 & 8 & 26 & 2 & & Marks (2007) \\
\hline Turks \& Caicos & 1.674 & 929 & 554 & 10 & & Marks (2007) \\
\hline USA & 2.406 & 2122 & 881 & 15 & & Marks (2007) \\
\hline Virgin Islands & 1.464 & 824 & 562 & 12 & & Marks (2007) \\
\hline \multicolumn{7}{|l|}{ Atlantic: Brazil } \\
\hline Abrolhos & 0.658 & 131 & 199 & 5 & & S. Floeter et al. (unpubl.) \\
\hline Arraial do Cabo & 2.405 & 457 & 190 & 11 & & S. Floeter et al. (unpubl.) \\
\hline St Paul's Rocks & 0.796 & 492 & 618 & 4 & & S. Floeter et al. (unpubl.) \\
\hline Guarapari & 0.660 & 373 & 565 & 8 & & S. Floeter et al. (unpubl.) \\
\hline Ilha Grande & 0.432 & 255 & 590 & 7 & & S. Floeter et al. (unpubl.) \\
\hline Laje de Santos & 0.418 & 51 & 122 & 5 & & S. Floeter et al. (unpubl.) \\
\hline F. Noronha & 0.356 & 144 & 404 & 9 & & S. Floeter et al. (unpubl.) \\
\hline Santa Catarina & 1.813 & 825 & 455 & 12 & & S. Floeter et al. (unpubl.) \\
\hline Trindade & 1.378 & 226 & 164 & 11 & & S. Floeter et al. (unpubl.) \\
\hline \multicolumn{7}{|l|}{ South Pacific } \\
\hline New Caledonia & 4.750 & 313 & 66 & 39 & Fished & Labrosse et al. (1999) \\
\hline New Caledonia & 1.550 & 575 & 371 & 34 & Unfished & Labrosse et al. (1999) \\
\hline Fiji & 0.400 & 203 & 508 & 25 & Fished & Labrosse et al. (1999) \\
\hline Fiji & 1.000 & 509 & 509 & 29 & Unfished & Labrosse et al. (1999) \\
\hline Tonga & 1.350 & 211 & 157 & 19 & Fished & Labrosse et al. (1999) \\
\hline Tonga & 1.300 & 501 & 386 & 29 & Unfished & Labrosse et al. (1999) \\
\hline Polynesia & 0.425 & 70 & 167 & 8 & Fished & Labrosse et al. (1999) \\
\hline Polynesia & 0.700 & 256 & 366 & 27 & Unfished & Labrosse et al. (1999) \\
\hline \multicolumn{7}{|l|}{ Unweighted averages } \\
\hline Atlantic-Caribbean & & & 458 & & & \\
\hline Atlantic-Brazil & & & 367 & & & \\
\hline South Pacific & & & 316 & & & \\
\hline
\end{tabular}


Floeter et al. unpubl. data) indicates values ranging from 122 to 590 piscivores ha $^{-1}$ for Brazil, with an average of 367 piscivores ha ${ }^{-1}$ (Table 6). A similar analysis in the South Pacific (where fishing intensity is probably lower than in most of the Caribbean; Stallings 2009) indicates lower densities of piscivores there, with a maximum of 509 piscivores ha ${ }^{-1}$ and an average of 316 piscivores ha $\mathrm{h}^{-1}$ (Table 6). In contrast, piscivore diversity is much higher in the South Pacific, with up to 39 species, whereas in the Atlantic the maximum is 15 species (Table 6). These preliminary data suggest a different density-diversity structure of piscivory in these regions. Therefore, the hypothesis that the success of lionfish in the Atlantic is linked to low piscivory levels may not be correct, unless lionfish are filling a functional piscivory niche that was not filled by evolutionary processes or that has been influenced and made vacant by fishing pressure. The densities of Pterois in the Atlantic are high for any piscivorous species, with the genus representing probably well over $30 \%$ of piscivorous species in some places. The current addition of such a sizeable abundance of piscivores is expected to cause a major imbalance in the reef-fish assemblages of the Atlantic (Albins \& Hixon 2011).

In conclusion, the distribution, abundance and ecology of lionfishes in their native Indo-Pacific range may provide some insight into what is causing their success in the Atlantic Ocean. Invasive lionfish almost certainly have escaped the natural controls that limit their density in their native range. This reality justifies reef managers in the invaded Atlantic range in actively limiting the abundance of these invaders by culling programs, provided that such activities do not harm the already stressed coral-reef ecosystems in the region.

Acknowledgements. The authors thank the many people who contributed data for this article. Data collection in the South Pacific was funded by the Institut de Recherche pour le Développement, the Ecole Pratique des Hautes Etudes, the European Union, the governments of New Caledonia and French Polynesia, the Programme National Récifs Coralliens and the Fondation pour le Recherche sur le Biodiversité (FRB). M.H., J.B., K.C., and J.M. acknowledge support from the US National Science Foundation (Grant no. 08-51162 to M.H.); K.C. was also funded by a scholarship from the Micronesian Area Research Center. Fieldwork in the Indian Ocean was supported by the Wildlife Conservation Society. through grants from the Western Indian Marine Science Association and through a grant from the Robert and Patricia Switzer Foundation. L.V. acknowledges support from the FRB and the Australian Institute of Marine Science.

\section{LITERATURE CITED}

Ackerman JL, Bellwood DR (2002) Comparative efficiency of clove oil and rotenone for sampling tropical reef fish assemblages. J Fish Biol 60:893-901

Adjeroud M, Letourneur Y, Porcher M, Salvat B (1998) Factors influencing spatial distribution of fish communities on a fringing reef at Mauritius, SW Indian Ocean. Environ Biol Fish 53:169-182

> Ahrenholz DW, Morris JA (2010) Larval duration of the lionfish, Pterois volitans along the Bahamian Archipelago. Environ Biol Fish 88:305-309

Albins MA, Hixon MA (2008) Invasive Indo-Pacific lionfish Pterois volitans reduce recruitment of Atlantic coral-reef fishes. Mar Ecol Prog Ser 367:233-238

Albins MA, Hixon MA (2011) Worst case scenario: potential long-term effects of invasive predatory lionfish (Pterois volitans) on Atlantic and Caribbean coral-reef communities. Environ Biol Fishes doi:10.1007/s10641-011-9795-1

- Almany GR, Webster MS (2006) The predation gauntlet: early post-settlement mortality in reef fishes. Coral Reefs 25:19-22

Alter C, Milton N, Reiniger M, von Mach V, Molenkamp B (2008) Assessment of the status of Kalawy Bay's fringing reef, Safaga, Egypt. Reef Check Germany, Bremen

Amesbury SS, Ginsburg D, Rongo T, Kirkendale L, Starmer J (1999) 'War-in-the Pacific' national historical park marine biological survey. University of Guam

Baker R, Sheppard R (2006) Fisheries resources of Albatross Bay, Gulf of Carpentaria, Information Series QI06062. Department of Primary Industries and Fisheries, Brisbane

Barbour AB, Montgomery ML, Adamson AA, Díaz-Ferguson E, Silliman BR (2010) Mangrove use by the invasive lionfish Pterois volitans. Mar Ecol Prog Ser 401:291-294

- Barott KL, Caselle JE, Dinsdale EA, Friedlander A and others (2010) The lagoon at Caroline/Millennium atoll, Republic of Kiribati: natural history of a nearly pristine ecosystem. PLoS One 5:e10950

Beets J, Brown E, Friedlander A (2010) Inventory of marine vertebrate species and fish-habitat utilization patterns in coastal waters off four national parks in Hawai'i. Tech Rep 168, Pacific Cooperative Studies Unit, University of Hawai'i at Mānoa

> Bellwood DR, Meyer CP (2009) Endemism and evolution in the Coral Triangle: a call for clarity. J Biogeogr 36: 2010-2012

> Berry PF, van der Elst RP, Hanekom P, Joubert CSW, Smale MJ (1982) Density and biomass of the ichthyofauna of a Natal littoral reef. Mar Ecol Prog Ser 10:49-55

- Bozec YM, Kulbicki M, Laloë F, Mou-Tham G, Gascuel D (2011) Factors affecting the detection distances of reef fish: implications for visual counts. Mar Biol 158:969-981

Brown JH (1984) On the relationship between abundance and distribution of species. Am Nat 124:255-279

Buckland ST, Anderson DR, Burnham KP, Laake JL, Borchers DL, Thomas L (2001) Introduction to distance sampling: estimating abundance of biological populations. Oxford University Press, Oxford

Carassou L (2008) Les assemblages de larves de poissons dans le lagon de Nouvelle-Calédonie: structure spatiotemporelle et relations avec les facteurs abiotiques et biotiques de l'environnement. PhD thesis, Université de Perpignan

Chen CY, Shao KT, Tu YY (2004) Effect of thermal dis- 
charges on the fish assemblages of a nuclear power plant in Northern Taiwan. J Mar Sci Technol 12:404-410

Chinea V, Chooramum V, Nallee M, Basant Rai Y, Hurbungs M, Paupiah CN (2001) Status of the marine environment of the Albion lagoon. In: Proc 4th Annu Meet Agr Sci. Food and Agricultural Research Council, Mauritius, p 195-210

Chou LM, Lim GSY, Leng CB (1992) Fish communities in natural reef and artificial habitats in the coastal waters of Brunei, Darussalam. In: Silvestre G, Matdanan HJH, Sharifuddin PHY, DeSilva MWRN, Chua TE (eds) The coastal resources of Brunei Darussalam: status, utilization and management. Proc ICLARM Conf 34:75-90

Cohen JE, Stephens DW (1978) Food webs and niche space. Princeton University Press, Princeton, NJ

Cole RG, Creese RG, Grace RV, Irving P, Jackson BR (1992) Abundance patterns of subtidal benthic invertebrates and fishes at the Kermadec Islands. Mar Ecol Prog Ser 82:207-218

Côté IM, Maljković A (2010) Predation rates of Indo-Pacific lionfish on Bahamian coral reefs. Mar Ecol Prog Ser 404: $219-225$

Cure K (2011) The ecology of lionfish in their native environment: insights into invasive success. MSc thesis, University of Guam

> Darling E, Green SJ, O'Leary JK, Côte I (2011) Indo-Pacific lionfish are larger and more abundant on invaded reefs: a comparison of Kenyan and Bahamian lionfish populations. Biol Invasions 13:2045-2051

de Boer WF, van Schieb AMP, Joceneb FD, Maboteb ABP, Guissamulob A (2001) The impact of artisanal fishery on a tropical intertidal benthic fish community. Environ Biol Fishes 61:213-229

de Troch M, Mees J, Wakwabi E (1998) Diets of abundant fishes from beach seine catches in seagrass beds of a tropical bay (Gazi Bay, Kenya). Belg J Zool 128:135-154

Doherty PJ (1987) Light-traps: selective but useful devices for quantifying the distributions and abundances of larval fishes. Bull Mar Sci 41:423-431

> Doherty PJ, Mc Ilwain JL (1996) Monitoring larval fluxes through the surf zones of Australian coral reefs. Mar Freshw Res 47:383-390

> Dufour V, Riclet E, Lo Yat A (1996) Colonization of reef fishes at Moorea Island, French Polynesia: temporal and spatial variation of the larval flux. Mar Freshw Res 47: 413-422

Durville P, Bosc P, Galzin R, Conand C (2002) Colonization of a fringing reef of Reunion Island by coral fish larvae. Oceanol Acta 25:23-30 (in French with English Abstract)

El-Dawi ESFA (1997) Fish diversity in correlation with some environmental factors in the mangal of two protectorate areas, Ras Muhammed and Nabq on the Red Sea in Egypt. Qatar Univ Sci J 17:377-385

El-Ganainy AAH, Yassien MH, Ibrahim EA (2005) Bottom trawl discards in the Gulf of Suez, Red Sea, Egypt. Egypt J Aquat Res 31:240-255

Feitoza BM, Rosa RS, Rocha LA (2005) Ecology and zoogeography of deep-reef fishes in northeastern Brazil. Bull Mar Sci 76:725-742

Fernando EFW (1972) Species composition of fish captured by trawlers in the Wadge Bank. Proc 13th Indo-Pacific Fisheries Council Fish Symp, Brisbane. Asian-Pacific Fishery Commission, Bangkok, p 521-531. www.apfic. org/Archive/symposia/1968/35.pdf

Fishelson L (1997) Experiments and observations on food consumption, growth and starvation in Dendrochirus brachypterus and Pterois volitans (Pteroinae, Scorpaenidae). Environ Biol Fishes 50:391-403

Freshwater DW, Hines A, Parham S, Wilbur AE and others (2009) Mitochondrial control region sequence analyses indicate dispersal from the US East Coast as the source of the invasive Indo-Pacific lionfish Pterois volitans in the Bahamas. Mar Biol 156:1213-1221

Froese R, Pauly D (eds) (2010) FishBase. Version 03/2010. www.fishbase.org

Galil BS (2007) Seeing red: alien species along the Mediterranean coast of Israel. Aquat Invasions 2:281-312

> Gell FR, Whittington MW (2002) Diversity of fishes in seagrass beds in the Quirimba Archipelago, northern Mozambique. Mar Freshw Res 53:115-121

Golani D, Sonin O (1992) New records of the Red Sea fishes Pterois miles (Scorpaenidae) and Pteragogus pelycus (Labridae) from the eastern Mediterranean Sea. Jpn J Ichthyol 39:167-169

Graham N, McClanahan T, Letourneur Y, Galzin R (2007) Anthropogenic stressors: inter-specific competition and ENSO effects on a Mauritian coral reef. Environ Biol Fish 78:57-69

Green SJ, Côté IM (2009) Record densities of Indo-Pacific lionfish on Bahamian coral reefs. Coral Reefs 28:107

Grubich JR, Westneat MW, McCord CL (2009) Diversity of lionfishes (Pisces: Scorpaenidae) among remote coral reefs of the Palau Archipelago. Coral Reefs 28:807

Hajisamae S, Yeesin P (2010) Patterns in community structure of trawl catches along coastal area of the South China Sea. Raffles Bull Zool 58:357-368

Halpern BS, Floeter SR (2008) Functional diversity responses to changing species richness in reef fish communities. Mar Ecol Prog Ser 364:147-156

Hamner RM, Freshwater DW, Whitfield PE (2007) Mitochondrial cytochrome $\mathrm{b}$ analysis reveals two invasive lionfish species with strong founder effects in the western Atlantic. J Fish Biol 71:214-222

Harborne AH, Fenner D, Barnes A, Beger M, Harding S, Roxburgh T (2000) Status report on the coral reefs of the east coast of peninsula Malaysia. Coral Cay Conservation, London

Hare JA, Whitfield PE (2003) An integrated assessment of the introduction of lionfish (Pterois volitans/miles complex) to the western Atlantic Ocean. Tech Mem NOS NCCOS 2, National Oceanic and Atmospheric Administration, Washington, DC

> Holway DA, Suarez AV (1999) Animal behavior: an essential component of invasion biology. Trends Ecol Evol 14: 328-330

Juncker M (2005) Approvisionnement en larves de poissons du lagon de Wallis (Pacifique Sud). PhD thesis, New Caledonia University, Nouméa

Kaunda-Arara B, Mwaluma JM, Locham GA, Øresland V, Osore MK (2009) Temporal variability in fish larval supply to Malindi Marine Park, coastal Kenya. Aquat Conserv 19:S10-S18

Kimball ME, Miller JM, Whitfield PE, Hare JA (2004) Thermal tolerance and potential distribution of invasive lionfish (Pterois volitans/miles complex) on the east coast of the United States. Mar Ecol Prog Ser 283:269-278

Kochzius M, Söller R, Khalaf MA, Blohm D (2003) Molecular phylogeny of the lionfish genera Dendrochirus and Pterois (Scorpaenidae, Pteroinae) based on mitochondrial DNA sequences. Mol Phylogenet Evol 28:396-403 
Kulbicki M (1998) How the acquired behaviour of commercial reef fishes may influence the results obtained from visual censuses. J Exp Mar Biol Ecol 222:11-30

Kulbicki M, Sarramégna S (1999) Adequacy of several density estimates obtained from underwater visual censuses: a case study of Chaetodontidae and Pomacanthidae. Aquat Living Resour 12:315-325

Kulbicki M, Wantiez L (1990) Comparison between fish bycatch from shrimp trawlnet and visual censuses in St. Vincent Bay, New Caledonia. Fish Bull 88:667-675

Kulbicki M, Cornuet N, Vigliola L, Wantiez L, Moutham G, Chabanet $P$ (2010) Counting coral reef fishes: interaction between fish life-history traits and transect design. J Exp Mar Biol Ecol 387:15-23

Labrosse P, Kulbicki M, Ferraris J (2001) Comptage visuel de poissons en plongée: conditions d'utilisation et de mise en oeuvre. Secrétariat Général de la Communauté du Pacifique, Nouméa, New Caledonia

Labrosse P, Letourneur Y, Kulbicki M, Magron F (1999) FISHEYE-a new database on the biology and ecology of lagoon and reef fishes of the South Pacific: example of its use on the ecology of commercial herbivorous fishes. In: Séret B, Sire JY (eds) Proc 5th Indo-Pacific Fish Conf, Nouméa, New Caledonia. Société Français d'Ichthyologie, Paris, p 657-672

Lambertini M, Leape J, Marton-Lefèvre J, Mittermeir RA and others (2011) Invasives: a major conservation threat. Science 333:404-405

Lecchini D, Polti S, Nakamura Y, Mosconi P, Tsuchiya M, Remoissonnet G, Planes S (2006) New perspectives on aquarium fish trade. Fish Sci 72:40-47

Letourneur Y (1996a) Influence of establishing marine reserves on fish populations: the case of Mayotte Island (western Indian Ocean). Ecoscience 3:442-450

Letourneur Y (1996b) Dynamics of fish communities on Reunion fringing reefs, Indian Ocean. I. Patterns of spatial distribution. J Exp Mar Biol Ecol 195:1-30

Letourneur Y (1998) Composition, structure et réseaux trophiques des peuplements de poissons de la côte au vent de l'île de La Réunion. Cybium 22:267-283

> Letourneur Y, Gaertner JC, Durbec JP, Jessu ME (2008) Effects of geomorphological zones, reefs and seasons on coral reef fish communities of Réunion Island, Mascarene Archipelago, SW Indian Ocean. Est Coast Shelf Sci 77:697-709

Lo-Yat A (2002) Variabilité temporelle de la colonisation par des larves de poissons de l'atoll de Rangiroa (Tuamotu, Polynésie française) et utilisation de l'outil 'otolithe' de ces larves. PhD thesis, University of French Polynesia, Tahiti

Locarnini RA, Mishonov AV, Antonov JI, Boyer TP, Garcia HE (2006) World Ocean Atlas 2005, Vol 1: Temperature. Levitus S (ed) Atlas NESDIS 61. National Oceanic and Atmospheric Administration, Washington, DC

Lugendo BR (2007) Utilization by fishes of shallow water habitats including mangroves and seagrass beds along the Tanzanian coast. PhD thesis, Radboud University, Nijmegen

Macnae W, Kalk M (1962) The ecology of the mangrove swamps of Inhaca Island, Moçambique. J Ecol 50:19-34

Malpot E (2005) Variations spatiales des captures de larves de poissons et d'invertébrés récifaux réalisés à l'aide de light-traps et comparaison de leurs performances à celles d'un filet de crête et d'un filet de hoa sur l'atoll de Rangiroa (Tuamotu, Polynésie française). Université de
Perpignan

Malpot E, Teitelbaum A, Raumea K, Story R (2008) Preliminary assessment of the potential for post-larval fish capture and culture: Aitutaki, Cook Islands. Secretariat of the Pacific Community, Nouméa

Marks KW (2007) AGRRA database, version 10/2007. Available at www.agrra.org/Release_2007-10

McIlwain JL (2003) Fine-scale temporal and spatial patterns of larval supply to a fringing reef in Western Australia. Mar Ecol Prog Ser 252:207-222

Meister HS, Wyanski DM, Loefer JK, Ross SW, Quattrini AM, Sulak K (2005) Further evidence for the invasion and establishment of Pterois volitans (Teleostei: Scorpaenidae) along the Atlantic coast of the United States. Southeast Nat 4:193-206

Mellin C (2008) Sélection de l'habitat à l'installation et utilisation de l'habitat post-installation chez les poissons récifaux-lagonaires de Nouvelle-Calédonie. PhD thesis, Université Pierre et Marie Curie, Paris

Mittelbach G (1986) Predator-mediated habitat use: some consequences for species interactions. Environ Biol Fishes 16:159-169

> Molnar JL, Gamboa RL, Revenga C, Spalding MD (2008) Assessing the global threat of invasive species to marine biodiversity. Front Ecol Environ 6:485-492

Mooney HA, Cleland EE (2001) The evolutionary impact of invasive species. Proc Natl Acad Sci USA 98:5446-5451

> Morris JA, Akins JL (2009) Feeding ecology of invasive lionfish (Pterois volitans) in the Bahamian archipelago. Environ Biol Fishes 86:389-398

Morris JA, Whitfield PE (2009) Biology, ecology, control and management of the invasive Indo-Pacific lionfish: an updated integrated assessment. Tech Mem NOS NCCOS 99, National Oceanic and Atmospheric Administration, Washington, DC

Morris JA, Akins JL, Barse A, Cerino D and others (2009) Biology and ecology of the invasive lionfishes, Pterois miles and Pterois volitans. Proc Gulf Caribb Fish Inst 29: 409-414

> Morris JA, Sullivan CV, Govoni JJ (2011) Oogenesis and spawn formation in the invasive lionfish Pterois miles and Pterois volitans. Sci Mar 75:147-154

> Mumby PJ, Edwards AJ, Arias-González JE, Lindeman KC and others (2004) Mangroves enhance the biomass of coral reef fish communities in the Caribbean. Nature 427:533-536

Mumby PJ, Harborne AR, Brumbaugh DR (2011) Grouper as a natural biocontrol of invasive lionfish. PLoS One 6: e21510

> Muñoz CR, Currin CA, Whitfield PE (2011) Diet of invasive lionfish on hard bottom reefs of the Southeast USA: insights from stomach contents and stable isotopes. Mar Ecol Prog Ser 432:181-193

Nakamura Y, Sano M (2004) Overlaps in habitat use of fishes between a seagrass bed and adjacent coral and sand areas at Amitori Bay, Iriomote Island, Japan: Importance of the seagrass bed as juvenile habitat. Fish Sci 70: 788-803

Newman SJ, Smith KA, Skepper CL, Stephenson PC (2008) Northern demersal scalefish managed fishery. ESD Rep Ser 6, Western Australia Fisheries and Marine Research Laboratories, North Beach

Ory N (2008) Etude préliminaire des communautés biologiques, benthique et halieutique au sein de la Baie de Ranobe, Sud-ouest de Madagascar. World Wildlife 
Federation, Gland

Oxley WG, Ayling AM, Cheal AJ, Osborne K (2004) Marine surveys undertaken in the Elizabeth and Middleton Reefs Marine National Nature Reserve, December 2003. Australian Institute of Marine Science, Townsville

Pimentel D, Zuniga R, Morrison D (2005) Update on the environmental and economic costs associated with alieninvasive species in the United States. Ecol Econ 52: 273-288

Pinca S, Beger M, Peterson E, Richards Z, Reeves E (2002) Coral reef biodiversity community-based assessment and conservation planning in the Marshall Islands: baseline surveys, capacity building and natural protection and management of coral reefs of the atoll of Rongelap. College of the Marshall Islands, Majuro

Pinto L (1987) Environmental factors influencing the occurrence of juvenile fish in the mangroves of Pagbilao, Philippines. Hydrobiologia 150:283-301

Ramm DC (1997) Assessment of groundfish stocks in Northern Australian waters between $123-137^{\circ} \mathrm{E}$. Fishery Rep No. 38, Northern Territory Department of Primary Industries and Fisheries, Darwin

Riclet E (1995) Colonisation récifale par les poissons autour de l'île de Moorea en Polynésie française. Master's thesis, Université Pierre et Marie Curie, Paris

Ruiz-Carus R, Matheson RE, Roberts DE, Whitfield PE (2006) The western Pacific red lionfish, Pterois volitans (Scorpaenidae), in Florida: evidence for reproduction and parasitism in the first exotic marine fish established in state waters. Biol Conserv 128:384-390

Rumpet R, Awang D, Musel J, Biusing R (1999) Distribution, abundance and biological studies of economically important fishes in the South China Sea, Area II: Sarawak, Sabah and Brunei Darussalam waters. Proc SEAFDEC Tech Sem Interdepart Collab Res Prog in South China Sea Area II, Kuala Lumpur, 14-15 December 1998, p 353-361. http://map.seafdec.org/pub.php

Sakai AN, Allendorf FW, Holt JS, Lodge DM and others (2001). The population biology of invasive species. Annu Rev Ecol Syst 32:305-332

Sandin SA, Smith JE, DeMartini EE, Dinsdale EA and others (2008) Baselines and degradation of coral reefs in the northern Line Islands. PLoS One 3:e1548

Schofield PJ (2009) Geographic extent and chronology of the invasion of non-native lionfish (Pterois volitans [Linnaeus, 1758] and P. miles [Bennett, 1828]) in the Western North Atlantic and Caribbean Sea. Aquat Invasions 4: 473-479

Schofield PJ (2010) Update on geographic spread of invasive lionfishes (Pterois volitans [Linnaeus, 1758] and P. miles [Bennett, 1828]) in the Western North Atlantic Ocean, Caribbean Sea and Gulf of Mexico. Aquat Invasions 5: S117-S122

Editorial responsibility: Matthias Seaman, Oldendorf/Luhe, Germany
Schroeder RE, Parrish J (2006) Ecological characteristics of coral patch reefs at Midway Atoll, northwestern Hawaiian Islands. Atoll Res Bull 543, Pacific Islands Fisheries Science Center, National Oceanic and Atmospheric Administration, Honolulu, HI, p 439-460

Schultz ET (1986) Pterois volitans and Pterois miles: two valid species. Copeia 1986:686-690

Sih A, Bolnick DI, Luttbeg B, Orrock JL and others (2009) Predator-prey naïveté, antipredator behavior, and the ecology of predator invasions. Oikos 119:610-621

Smith A, Dalzell P (1991) Fisheries resources and management investigations in Woleai Atoll, Yap State, Federated States of Micronesia. Inshore Fisheries Res Proj Tech Doc No. 4, South Pacific Commission, Nouméa

> Stallings CD (2009) Fishery-independent data reveal negative effect of human population density on Caribbean predatory fish communities. PLoS One 4:e5333

Suharsono, Giyanto, Yahmantoro, Munkajee AJ (1995) Changes of distribution and abundance of reef fish in Jakarta Bay and Seribu islands. In: Soemodihardjo S (ed) Proc Coral Reef Eval Workshop, Pulau Seribu, Jakarta, 11-20 September 1995, p 37-54. http://elib.pdii.lipi.go. id/katalog/index.php/searchkatalog/byId/38

Thollot P (1993) Western Samoa mangrove fish survey. ORSTOM, Nouméa

Valentine J, Edgar G, Dudding J, Gudge S, Kerr I (2008) Monitoring of biotic changes at Lord Howe Island Marine Park, New South Wales. New South Wales Marine Parks Authority, Cronulla

Vermond S, Fabre NJ, Lecaillon G, Bosc P, Chabanet P (2009) Post-larval capture and culture (PCC) technology: a sustainable alternative for the marine aquarium trade and the conservation of biodiversity at Reunion Island (SW Indian Ocean). Proc 6th West Indian Ocean Mar Sci Assoc Conf, La Réunion Western Indian Ocean Marine Science Association, Zanzibar

Verweij MC, Nagelkerken I, de Graaff D, Peeters M, Bakker EJ, van der Velde G (2006) Structure, food and shade attract juvenile coral reef fish to mangrove and seagrass habitats: a field experiment. Mar Ecol Prog Ser 306: $257-268$

Weis JS, Weis P (2005) Use of intertidal mangrove and sea wall habitats by coral reef fishes in the Wakatobi Marine Park, Indonesia. Raffles Bull Zool 53:119-124

- Whitfield PE, Gardner T, Vives SP, Gilligan MR, Courtenay WR Jr, Ray GC, Hare JA (2002) Biological invasion of the Indo-Pacific lionfish Pterois volitans along the Atlantic coast of North America. Mar Ecol Prog Ser 235:289-297

Whitfield PE, Hare JA, David AW, Harter SL, Muñoz RC, Addison CM (2007) Abundance estimates of the IndoPacific lionfish Pterois volitans/miles complex in the western North Atlantic. Biol Invasions 9:53-64 (and Erratum (2007) 9:231)

Submitted: November 18, 2010; Accepted: October 7, 2011 Proofs received from author(s): January 24, 2012 